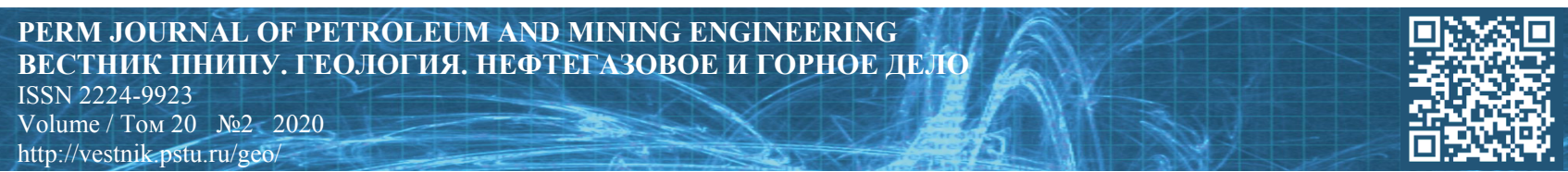

UDC 622.276.4:678.01

Article / Статья

(C) PNRPU / ПНИПУ, 2020

\title{
LABORATORY STUDY OF INFLUENCE OF RHEOLOGICAL CHARACTERISTICS OF CROSS-LINKED POLYMER SYSTEMS ON PERMEABILITY AND OIL DISPLACEMENT COEFFICIENTS
}

\section{Vadim lu. Ogoreltcev, Sergei A. Leontev ${ }^{1}$, Valentin A. Korotenko ${ }^{1}$, Sergei I. Grachev ${ }^{1}$, Valerii F. Diagilev ${ }^{2}$, Oleg V. Fominykh ${ }^{1}$}

SurgutNIPIneft (Tyumen branch) (12 Rosa Luxemburg st., Tyumen, 625003, Russian Federation) ${ }^{1}$ Tyumen Industrial University (38 Volodarsky st., Tyumen, 625000, Russian Federation)

${ }^{2}$ Branch of the Tyumen Industrial University in Nizhnevartovsk (2P Lenina st., building 9, 628000, Nizhnevartovsk, Russian Federation)

\section{ЛАБОРАТОРНЫЕ ИССЛЕДОВАНИЯ ВЛИЯНИЯ РЕОЛОГИЧЕСКИХ ХАРАКТЕРИСТИК СШИТЫХ ПОЛИМЕРНЫХ СИСТЕМ НА КОЭФФИЦИЕНТЫ ПРОНИЦАЕМОСТИ И ВЫТЕСНЕНИЯ НЕФТИ}

\section{В.Ю. Огорельцев, С.А. Леонтьев ${ }^{1}$, В.А. Коротенко ${ }^{1}$, С.И. Грачев ${ }^{1}$, В.Ф. Дягилев ${ }^{2}$, О.В. Фоминых} «СургутНИПИнефть» (Тюменское отделение) (625003, г. Тюмень, ул. Розы Люксембург, 12)

${ }^{1}$ Тюменский индустриальный университет $(625000$, г. Тюмень, ул. Володарского, 38$)$

${ }^{2}$ Филиал Тюменского индустриального университета в г. Нижневартовске (628000, г. Нижневартовск, ул. Ленина 2/П, строение 9)

Received / Получена: 24.02.2020. Accepted / Принята: 15.04.2020. Published / Опубликована: 15.06.2020

\section{Key words:}

enhanced oil recovery methods, permeability coefficient, oil displacement coefficient, linear filtration rate, viscosity and temperature characteristics of polymer compositions, acrylamide polymer.

\begin{abstract}
In development of hard-to-recover hydrocarbon reserves, enhanced oil recovery methods are applied on a massive scale, chemical methods being the most common ones. Each formation stimulation technology is associated with certain application conditions which depend on the initial geological and physical formation parameters and current state of its development

Methodological approach is provided for determination of permeability coefficient and coefficient of oil displacement from rock during testing of compositions of technologies of physical and chemical enhanced oil recovery methods on the basis of laboratory studies of rheological properties of various brands of acrylamide polymer. The methods have been developed according to the requirements to core analysis. The study provides a list of equipment and basic characteristics of the filtration system, as well as the requirements to core analysis. The study provides a list of equipment and basic characteris

paboratory study of gel systems' rheological properties is performed on the basis of the technological process for preparation of components of viscoelastic compound recipe at the wellhead and its further injection into the formation. To this end, in order to components of viscoelastic compound recipe at the wellhead and its further injection into the formation. To this end, in order to
determine the rheological properties of gel systems, a special-purpose rheometer was used, with a capability to dynamically register the changing viscosity data of the tested polymer systems prepared on the analogues of fresh, produced and Cenomanian waters in "well formation" thermobaric conditions. Based on the laboratory studies, it has been shown that trial injections of cross-linked compositions on the basis of polyacrylamide (PAA) of brands FP-107 and Poly-T-101, possessing the capability of multifold increase of final viscosity of the polymer composition (by 2-3 times and more) in conditions of increasing temperature in low salinity waters (produced, Cenomanian), enable higher technological effectiveness compared to brand FP-307 polyacrylamide presently used in the company's oilfields.
\end{abstract}

При разработке трудноизвлекаемых запасов углеводородов нефтяных месторождений массово применягося методы увеличения нефтеотдачи, основными из которых являются химические. Каждая технология воздействия на методы увеличения нефтеотдачи, основными из которых являются химические. Каждая технология воздействия на пласт обладает определенными условиями при

Пласта и текущего состояния его разработки. испытании составов технологий физико-химических методов увеличения нефтеотдачи на основе лабораторных исследований реологических свойств различных марок полимера акриламида. Методики разработаны в соответствии с требованиями по исследованию керна. Приведен перечень оборудования и основные характеристики фильтрационной системы, а также порядок подготовки рабочих жидкостей и моделей пласта к проведению лабораторных исследований.

Осуществление лабораторных исследований реологических свойств гелевых систем выполнено исходя из особенностей технологического процесса приготовления компонентов рецептуры вязкоупругого состава на устье скважины и последующей его закачки в пласт. С этой целью для определения реологических характеристик гелевых систем использовался специализированный реометр, который позволяет в динамическом режиме фиксировать данные изменения вязкостных свойств испытуемых полимерных систем, приготовленных на моделях пресной, подтоварной и сеноманской вод в термобарических условиях «скважина - пласт». На основании лабораторных исследований показано что проведение термобарических условиях «скважина - пласт». На основании лабораторных исследований показано, что проведение опытных закачк сшит компзиций на основе полиакриламида (ПАА) марок FР-107 и Роly-Т-101, обладающих способностью кратного повышения конечной вязкости полимерного состава (в 2-3 раза и более) с ростом температуры в сравнению с применяемым в настоящее время на месторождениях компании полимером акриламидом марки FР-307.

\footnotetext{
Vadim Iu. Ogoreltcev (Scopus ID 56310901500) - Head of the Laboratory (tel: +007 34526872 04, e-mail: Ogoreltsev_VU@surgutneftegas.ru).

Sergei A. Leontev (Scopus ID 36015591300) - Doctor of Engineering, Professor at the Department of Development and Operation of Oil and Gas Fields (tel.: +007 3452283026 , +00791993097 51, e-mail: leontevsa@tyuiu.ru). The contact person for correspondence.

Valentin A. Korotenko (Scopus ID 57203508819) - PhD in Engineering, Associate Professor at the Department of Development and Operation of Oil and Gas Fields (tel.: +00734522830 26, e-mail: korotenkova@tyuiu.ru).

Sergei I. Grachev (Scopus ID 57195921058) - Doctor of Engineering, Professor, Head of the Department of Development and Operation of Oil and Gas Fields (tel.: +007 3452283026 , e-mail: grachevsi@tyuiu.ru).

Valerii F. Diagilev (Scopus ID 57194202350) - PhD in Engineering, Associate Professor at the Department of Oil and Gas Business (tel.: +007 346361 20 82 , e-mail: djagilevvf@tyuiu.ru).

Oleg V. Fominykh (Scopus ID 36061643100) - PhD in Engineering, Associate Professor at the Department of Development and Operation of Oil and Gas Fields Oleg V. Fominykh (Scopus ID 36061643100) - PhD
(tel.: +007 34522830 26, e-mail: fominyhov@tyuiu.ru).

Огорельцев Вадим Юрьевич - заведующий лабораторией (тел.: +007 34526872 04, e-mail: Ogoreltsev VU@surgutneftegas.ru).

Леонтьев Сергей Александрович - доктор технических наук, профессор кафедры «Разработка и эксплуатация нефтяных и газовых месторождений» (тел.: +007345228 $3026,+0079199309751$, e-mail: leontevsa $(a$ tyuiu.ru). Контактное лицо для переписки.

Кер.: коротенко Валентин Алексеевич - кандидат техин

Грачев Сергей Иванович - доктор технических наук, профессор, заведующий кафедрой «Разработка и эксплуатация нефтяных и газовых месторождений» Грачев Сергей Иванович - доктор технических науи

Дягилев Валерий Федорович - кандидат физико-математических наук. доцент кафедры «Нефтегазовое дело» (тел.: +007 34636120 82. e-mail: diagilevvf(@tvuiu.ru). Фоминых Олег Валентинович - кандидат технических наук, доцент кафедры «Разработка и эксплуатация нефтяных и газовых месторождений» (тел.: +007 34522830 26, e-mail: fominyhov@tyuiu.ru).
} 


\section{Introduction}

Today more than $90 \%$ of the remaining recoverable reserves in commercial category oilfields are hard-to-recover (high watercut, gas-oil, complex structure, low production, etc.). According to the native and global experience, effective development of hardto-recover reserves by waterflooding is impossible without massive application of enhanced oil recovery (EOR) methods, chemical (CEOR) methods being the most common ones. Starting from the stage of advancing water production, CEOR methods enable cost-effective improvement of oil recovery ratio by $3-$ $15 \%$ and more and significantly extend the period of cost-effective formation development [1-10].

Each formation stimulation technology has its own application conditions which depend on the initial geological and physical formation parameters and current state of its development. Failure to observe these conditions (applicability criteria) can lead to a failure to obtain the expected amount of incremental oil and oil recovery ratio [11-14].

In order to maintain and improve specific effectiveness of the technologies, and to achieve higher recovery in uninvaded zones of formations, the solution volume of the injected plugs of flow diverter compounds is planned to be increased by $10-15 \%$ annually, with an increase in chemical reagents concentration $[15,16]$.

Structural scheme of formation stimulation chemical methods is shown in fig. 1.

CEOR methods can be provisionally divided into two groups:

- bottom hole treatment (BHT) of the well in order to stimulate the formation (formation BHT);

- flow diverting methods of enhanced oil recovery (FDEOR) [17-20].

BHT methods can be provisionally divided into two subgroups:

- using acid compositions;

- using hydrocarbon solvent and surfactants.

Based on the formation stimulation mechanism, flow diverting enhanced oil recovery methods can be provisionally divided into three subgroups:

- methods for stabilizing the injection well water intake profile with emulsion compounds (emulsionbased SWIP) [26-31];

- methods for stabilizing the water intake profile and front of oil displacement with water (SWIP and FODW) based on polymers, gels and particulate fillers [21-25];

- surfactant-based methods assisting residual oil sweeping $[11,32,33]$.

Further discussed are the methods for stabilizing the water intake profile and front of oil displacement with

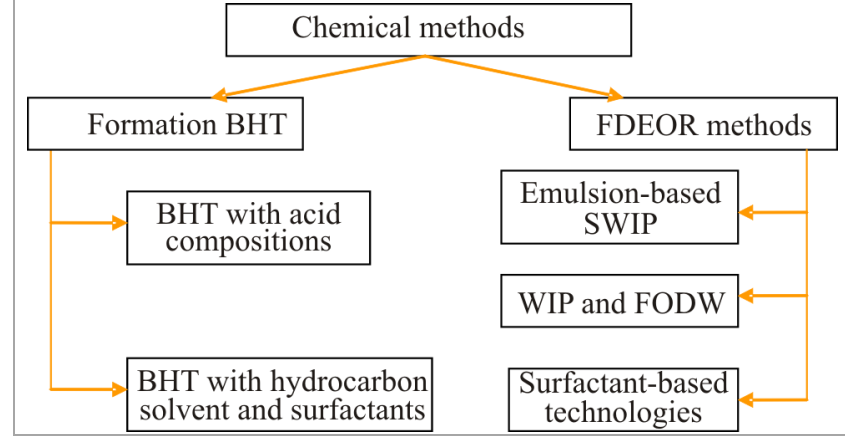

Fig. 1. Classification of chemical enhanced oil recovery methods

water (SWIP and FODW). According to the current concepts of oil displacement mechanics in porous media, front of oil displacement with water is configuration, by section and formation area, of the conventional interface line between zones with oil saturation approximating the initial state and zones containing injected water in the composition of saturating fluids. Such definition does not contradict the established fact of outpacing water saturation increase up to the critical value in uninvaded purely oil-filled formation zones long before entry of injection water. This phenomenon is most apparent in low permeability reservoirs and can be explained by high mobility of residual water caused by differential pressure increase (start of oil injection in injection wells). Depression cone expansion in producing wells leads to "squeezing" of loosely bound water from underlying and overlying clays. In the initial period of formation development (formation pressure equal to initial pressure) this phenomenon can be neglected, taking into account water permeability of clays $\left(10^{-6}-10^{-7} \mu \mathrm{m}^{2}\right)$, but within the depression cone, at shale streak thickness of $2 \mathrm{~m}$, the volume of additional water penetrating through it into the well can amount to $20 \mathrm{~m}^{3} /$ day (at maximum formation potential recovery values). Due to these factors, product watercut in low output wells may be substantial, which can lead to misconceptions regarding the displacement front configuration at the initial stages of formation development.

Stabilization of the front of oil displacement with water suggests activities aimed at ensuring maximally uniform distribution of injected water flows, in the section and across the area of the zones distant from the injection wells, in order to ensure maximum ultimate oil recovery. Since the effect of compositions on the formations starts in the immediate vicinity of BHZ, FODW technology doesn't exist in pure form. Initially these technologies facilitate SWIP and further, as the plug progresses through the formation, in the uninvaded interwell space - FODW. Methods stabilizing the water intake profile and front of oil displacement with water are, primarily, polymerbased technologies [15, 16, 21-25]. 
Polymer gelling agent (PGA) technology is the basis for other polymer-based technologies and one of the most common flow diverting technologies that were and have been in use in Surgut region wells (9800 well jobs, or $20.8 \%$ of all well jobs in 1991-2017). PGA injection volume varied from 50 to $550 \mathrm{~m}^{3}$ per well job. The reagents in use are polyacrylamide (PAA) by Accotrol, GS-1, DKS and others, with concentrations of $0.2-0.6 \%$, cross-links - chromium acetate, chromium-potassium sulfate and others with concentrations of $0.02-0.07 \%$ [34].

The technology aims to increase the sweep efficiency and stabilization of displacement front, which is achieved by creating excessive filtration resistances in water-swept intervals of the formation by way of polymer cross-linking in the formation. PGA effectiveness first of all depends on accuracy of computation of its optimum injection volume for each stimulated well. In case of insufficient volume, filtration resistance will be low, and SWIP will not be achieved; too high PGA injection volume can lead to temporary blocking of oil saturated formation intervals, which also impedes reaching SWIP.

\section{Methodological approach for determination of permeability coefficient and coefficients of oil displacement from rock during testing of compositions for technologies of physical and chemical EOR methods}

Methods for measurement of permeability coefficients and coefficients of oil displacement from reservoir rock during testing of compositions for the technologies of physical and chemical enhanced oil recovery methods have been developed according to the requirements of GOST 26450.0-85, GOST 26450.2-85 [36, 37], OST 39-195-86 [38] and OST 39-235-89 [39]. The methods are applied to oil-containing rock and establish the procedure for measurement of these coefficients in laboratory conditions.

The target of testing is laboratory formation made of cylindrical rock samples of correct geometrical shape drilled from whole core of the oil-bearing horizon under research. The testing conditions shall ensure replication of natural physical and chemical characteristics of the "rock-fluid" formation system, preservation of temperature and pressure values of the formation during the experiment. Linear flow rate of the tested fluids through the rock in time shall match its production values in the formation areas proximal to or distant from the well. During the test it is necessary to use reservoir oil and water or their laboratory analogues, as well as chemical compounds used as working agents in SWIP technologies [40, 41].

\section{Equipment}

Filtration system (hereinafter the system) for testing of compositions of technologies of oil production stimulation and enhanced oil recovery shall consist of interrelated functional blocks ensuring performance of testing operations in thermobaric conditions simulating reservoir conditions (table 1).

Table 1

Basic characteristics of filtration systems

\begin{tabular}{|l|c|}
\hline \multicolumn{1}{|c|}{ Parameter } & Value \\
\hline Maximum confining pressure, $\mathrm{MPa}$ & Minimum 68.0 \\
\hline Maximum pore pressure, $\mathrm{MPa}$ & Minimum 40.8 \\
\hline Maximum operating temperature, ${ }^{0} \mathrm{C}$ & Minimum 150 \\
\hline Permeability variation range, $\mathrm{mD}$ & 0.001 to 5000 \\
\hline Pump discharge variation range, $\mathrm{cm}^{3} / \mathrm{min}$ & 0.00001 to 50 \\
\hline & Hastelloy C-276, \\
Pore fluid contacting surface material & Titanium, Viton, \\
& Peek, Teflon \\
\hline
\end{tabular}

The system's principal arrangement includes the following main blocks:

- tested fluid injection;

- formation factors simulation;

- confining pressure control;

- back pressure control for filtration flow;

- system control and experiment data recording.

\section{Preparation of working fluids to testing}

Tests determining formation rock permeability and residual oil saturation use samples of pure oil and water, and process liquids used as working agents in development of a specific oil field facility (formation). In absence of formation fluid samples, their laboratory analogues are acceptable.

Physical analogues of formation oil can be degassed oil diluted with organic solvent (petroleum ether, hexane, gasoline, kerosene, etc.). The main criteria of analogue oil matching the reservoir gas-saturated oil is equality of their rheological characteristics (viscosity, density) in formation condition [34]

Formation water analogue is prepared by dissolving chloride salts $\left(\mathrm{NaCl}, \mathrm{CaCl}_{2}\right.$, etc.) in distilled water. Content of salts should correspond to total salinity of formation water. Qualitative and quantitative composition of salts is calculated on the basis of formation water chemical analysis results and salinity value assumed for the formation under study converted to sodium chloride.

Preparation of compositions of physical and chemical EOR methods to improve well productivity, stabilize well water intake profile, front of residual oil displacement and sweeping, as well as process liquids 
used in well construction, testing and further operation, is performed under the requirements stipulated by guideline documents regulating respective geological and technical activities.

\section{Laboratory formation preparation to testing}

Filtration tests of compositions of physical and chemical stimulation of the formation use cylindrical rock samples of correct geometrical shape drilled from whole core, 30 and $38 \mathrm{~mm}$ in diameter and at least $27 \mathrm{~mm}$ long. Prior to the tests, samples are extracted in alcohol-benzene mixture for complete removal of hydrocarbons from their void space and, in case of high (more than 50-100 g/L) salinity of formation (residual) water, are desalted in Soxlet apparatus. Next, samples stripped of hydrocarbons and formation water salts are dried to constant weight with accuracy up to $\pm 0.001 \mathrm{~g}$ in a drying oven at $105 \pm 2{ }^{\circ} \mathrm{C}$ during $12 \mathrm{~h}$. The dried samples of rock are cooled in the desiccator above tempered calcium chloride to ambient temperature during 2-3 $\mathrm{h}$, followed by determination of their porosity and permeability. Based on the known values of permeability of individual core samples to gas (nitrogen, helium) they are arranged in the laboratory formation, based on the condition that each subsequent sample in the composite column is less permeable than the previous, provided that the permeability variance between the two adjacent samples shall not exceed 10-15\%. Depending on the tasks solved during simulation of processes of stimulation of well bore zone or uninvaded zone of the formation with chemical reagent solutions, determination of rock permeability to liquid (to water - in case of water displacement, to oil or water - in case of change in rock fluid conductivity) is performed in the course of its filtration through the laboratory formation in the direction of porous medium permeability reduction.

Water saturation of the laboratory formation arrangement prior to the tests is created using centrifuging method ensuring conformity of residual water content in the void space of individual samples to its quantity in reservoir conditions. The method consists in displacement of excessive water from the fully water-saturated sample by centrifuging due to creation of capillary pressure at the air-water phase interface in rock pores. The ultimate stage of laboratory formation preparation is saturation of core samples bearing replicated residual water with kerosene in the desiccator by vacuum treatment during at least $4 \mathrm{~h}$.

\section{Filtration system preparation to testing}

The procedure of system preparation activities prior to testing includes:
- filling the reservoirs with tested fluids (formation samples of oil, water or their laboratory analogues, chemical reagent solutions);

- loading the laboratory formation made up of core samples into the rubber collar of the core holder, connection of fluid conducting tubes;

- leakage check of the system's hydraulic circuit by way of creating confining (rock) pressure and pore (formation) pressure in the core holder corresponding to oil formation factors;

- heating up system components (reservoirs, core holder, separator, etc.) to formation temperature;

- customizing the software and experiment sequence, creating log file;

- displacement of kerosene with oil by way of its pumping through the laboratory formation in the amount not less than 3-4 pore volumes in constant flow maintenance mode, not exceeding linear filtration rate of $1 \mathrm{~m} /$ day;

- laboratory formation dwell period for $12-16 \mathrm{~h}$ at thermobaric conditions to stabilize "rock-fluids" system.

\section{Measurement of permeability coefficient}

The measurement method is based on assessment of reservoir rock permeability to the filtered fluid (water, oil, or their laboratory analogues) before and after its treatment with chemical reagent solutions. The method consists in testing the compositions of technologies for production stimulation and enhanced oil recovery of reservoirs in composite columns consisting of core samples, whose effectiveness, depending on the purpose of use (well productivity increase, well water intake profile and displacement front stabilization, residual oil sweeping, etc.) is determined by the change in rock fluid conductivity.

During tests, filtration of the tested fluids (oil, water, chemical reagent solutions) through the laboratory formation is performed with constant flow rate throughout the experiment. The flow rate is determined on the basis of linear flow rate in the zones proximal to and distant from the well (1) [42-45]:

$$
V=\frac{864 Q}{F \cdot m\left(1-S_{\text {w.resid }}-S_{\text {o.resid }}\right)},
$$

where $V$ - linear filtration rate, $\mathrm{m} /$ day; $Q$ - filtered liquid flow, $\mathrm{cm}^{3} / \mathrm{s} ; F$ - laboratory formation crosssection area, $\mathrm{cm}^{2} ; m$ - laboratory formation porosity, decimal quantity; $S_{\mathrm{w} . \text { resid }}, S_{\text {o.resid }}$ - residual water and oil saturation of laboratory formation in formation conditions, respectively, decimal quantity.

Measurement of coefficient of the laboratory formation permeability to liquid (oil, water) is 
performed after its pumping through the rock in the minimum amount of 4-6 pore volumes and in presence of pressure gradient at composite column face ends.

Calculation of the coefficient of formation rock permeability to liquid is performed on the basis of a formula of Darcy's linear filtration law (2):

$$
K=\frac{Q L \mu}{\Delta P F},
$$

where $K$ - rock permeability to liquid, $\mu \mathrm{mg} ; Q$ - liquid volumetric flow rate, $\mathrm{cm}^{3} / \mathrm{s} ; L$ - length of sample part on which pressure differential is measured, $\mathrm{cm} ; F-$ sample cross-section area in the sample's measured part, $\mathrm{cm}^{2} ; \mu$ - liquid viscosity in the experiment conditions, $\mathrm{mPa} \cdot \mathrm{s} ; \Delta P$ - pressure differential in the sample's measured part at the given filtration mode, $10^{5} \mathrm{~Pa}$.

\section{Measurement of oil displacement coefficient}

The measurement method suggests determining oil recovery ratio from laboratory formation by means of filtration of displacing agents (water, chemical reagent solutions) through its void space until saturated watercut of the fluid being recovered is reached. The method consists in simulation of the process of waterflooding productive horizons. Combining waterflooding with injection of plug compositions of flow correcting technologies helps establish additional increment of residual oil displacement.

Oil displacement from laboratory formation is performed at constant flow for all injected liquids, which has to correspond to real or project (expected) linear rate (1) of their filtration in the formation zone distant from the well.

Procedure for measurement of oil displacement coefficients in the course of technology compositions testing consists of the following stages:

- continuous displacement of oil with water until saturated watercut of liquid discharged from the core holder, but not less than 4-6 pore volumes of laboratory formation. Initial volume of water-displaced oil is determined by indications of the acoustic separator;

- injection into laboratory formation of plug compositions of flow correcting technologies from 0.5 to 4 pore volumes, whose quantity during testing is assumed on the basis of the actual process of chemical reagents injection into the formation;

- injection into laboratory formation of water plug in the amount of 4-6 rock pore volumes. Final volume of incrementally displaced oil after filtration of plugs of technology compositions is determined using the retort method.

The achieved increment of residual oil recovery $\Delta K_{\text {displ. }}$ after use of technology compositions is determined from the difference between final $K_{\text {displ.fin }}$ and initial $K_{\text {displ.init }}$ displacement coefficients (3):

$$
\Delta K_{\text {displ }}=K_{\text {displ.fin }}-K_{\text {displ.init }} .
$$

Initial (oil displacement with water) and final (after injection of technology compositions) oil displacement coefficients are calculated by formulas (4), (5):

$$
\begin{aligned}
& K_{\text {displ.init }}=\frac{V_{\text {o.sep }}}{V_{\text {o.init }}} 100 \% ; \\
& K_{\text {displ.fin }}=\frac{V_{\text {oret }}}{V_{\text {o.init }}} 100 \%,
\end{aligned}
$$

where $K_{\text {displ.nnit }} K_{\text {displ.fin }}$ - oil displacement coefficients before and after injection of technology compositions through the laboratory formation, respectively, \%; $V_{\text {o.sep }}, V_{\text {o.ret }}$ - displaced oil volumes according to the acoustic separator and extraction retort indications, respectively, normalized to testing conditions, $\mathrm{cm}^{3}$; $V_{\text {o.init }}$ - oil volume initially contained in the laboratory formation, determined by the difference between void volume and residual water, normalized to testing conditions, $\mathrm{cm}^{3}$.

Residual oil content in laboratory formation after injection of technology compositions is determined by formula (6):

$$
S_{\text {o.resid }}=\frac{V_{\text {o.init }}-V_{\text {o.ret }}}{V_{\text {п }}} 100 \%,
$$

where $S_{\text {o.resid }}$ - residual oil saturation of laboratory formation after injection of technology compositions, \%; $V_{n}$ - pore volume of laboratory formation made up of core samples, $\mathrm{cm}^{3}$.

\section{Acrylamide polymer brands laboratory analysis results}

A series of laboratory analyses was conducted in order to establish the declared rheological characteristics of cross-linked polymer systems on the basis of acrylic polymer (PAA) brands accepted for testing and laboratory assessment of effectiveness of the viscoelastic composition technology (VEC) intended for redistribution of injected water flows during stabilization of water intake profile and displacement front of injection wells in compartmentalized and nonuniform permeability formations. The first stage of the works was studying rheological properties of polymer systems with simulation of thermobaric parameters of the technological process of VEC recipe preparation at the wellhead and its further injection into the formation. 
Another subject of this series of tests was impact of salinity of water used for makeup of gel systems. The second stage consisted in filtration tests of cross-linked gel structures on highly permeable core analogues of $\mathrm{VK}_{1}$ horizon of field R. Laboratory works were comparative and based on the juxtaposition of technological indicators - those of the reagents proposed for the pilot test (Poly-T-101, FP-107, FP-207 and PoLEOR ATC N800) and of the PAA brands already tested in the compositions of flow diverting technologies in PJSC Surgutneftegaz fields (FP-307, Accotrol S-622).

First stage. Until now, there is no commonly accepted method of laboratory testing of acrylic polymer compositions at oil deposit thermobaric conditions of occurrence. This is caused by absence of justified theory and single opinion concerning the mechanism of spatial cross-linking of PAA water soluble molecules by ions of polyvalent metals in pore space of reservoir rocks. To this end, in order to determine rheological characteristics of gel systems, a special-purpose rheometer was used to capture the dynamics of viscosity properties of the tested polymer systems mixed on the analogues of fresh, produced, and Cenomanian waters in "well-formation" thermobaric conditions. The following conditions were observed during the experiments for simulation of thermobaric parameters of the technological process of VEC recipe makeup:

1. Dissolution of gelling agent in the solvent at constant stirring with an agitator (300 rpm) during 30 minutes at $22-25^{\circ} \mathrm{C}$ with further addition of a crosslinking agent to the solution.

2. Temperature intervals of heating of the crosslinked polymer system in the experiment:

- heating from 25 to $40{ }^{\circ} \mathrm{C}$ during 30 minutes;

- conducting the experiment with uniform temperature increase to $70{ }^{\circ} \mathrm{C}$ during $24 \mathrm{~h}$.

3 . Establishing dynamic viscosity values of the tested composition at shear rate $100 \mathrm{1} / \mathrm{s}(117.6 \mathrm{rpm})$ and liquid pressure in the viscosity meter system $7 \mathrm{MPa}$.

Adherence to these conditions was replicated by actual makeup time of linear gel and cross-linking agent
(30-40 min), their mixing in the turbulent flow during feeding through the well tubing string (WTS) to well bottom (20-30 min) and further dwell period of the polymer system required to form the cross-link in the formation (at least 12-24 h). In the experiments, special focus was made on the temperature intervals of heating of cross-linked gel samples:

- for polymer composition injection into the formation - temperature increase from 20 to $40{ }^{\circ} \mathrm{C}$ during 30 minutes.

- for spatial cross-linking of PAA molecules in rock void space - uniform temperature increase to $70^{\circ} \mathrm{C}$ during $24 \mathrm{~h}$. This corresponds to the polymer system heating rate to formation temperature in the area of the well bottom hole zone cooled by the injected water.

Provided that the stipulated concentrations of gelling agent $\left(\mathrm{C}_{\mathrm{PAA}}=0.4 \mathrm{wt} . \%\right)$ and cross-linking agent $\left(\mathrm{C}_{\mathrm{CA}}=0.04\right.$ wt. \%) are observed, polymer structures demonstrate high values of initial dynamic viscosity (40 to $80 \mathrm{mPa} \cdot \mathrm{s}$ ), which is caused by the final stage of cross-linking microgel complexes due to nearly complete dissolution of PAA in distilled water over a relatively short period of time (30-40 minutes). Among the tested PAA brands, an exception is PoLEOR ATC N800, which does not manifest high thermal stability in fresh water and loses its viscosity properties by more than 2.5 times when the tested sample heating temperature increases up to $50-60{ }^{\circ} \mathrm{C}$.

During makeup of VEC technology compositions on analogue types of produced and Cenomanian water, except for the solution based on Accotrol S-622 reagent $\left(\mathrm{C}_{\mathrm{NaCl}}=5 \mathrm{~g} / \mathrm{L}\right)$, on the contrary, the primary factor influencing maintenance of stable viscosity and temperature characteristics of hydrogels is detrimental influence of low mineralization of salts contained in solvents. This is caused by low initial viscosity values of the systems (10 to $17 \mathrm{mPa} \cdot \mathrm{s})$ due to the time lag of intramolecular cross-linking processes in the entire bulk of polymer compositions whose intensity grows not earlier than after 4-6 h. Besides, in the course of testing it was noted that kinetics of spatial formation of gel in acrylamide polymers in saline solutions and in fresh

Table 2

Viscosity and temperature characteristics of polymer compositions based on samples of polyacrylamide cross-linked with chromium acetate $\left(C_{\mathrm{PAA}}=0.4 \mathrm{wt} . \%, C_{\mathrm{CA}}=0.04 \mathrm{wt}\right.$. \%)

\begin{tabular}{|c|c|c|c|c|c|c|c|}
\hline \multirow{2}{*}{$\begin{array}{c}\text { Analogue water (solvent) } \\
\text { type }\end{array}$} & Poly-T-101 & Poly-T-101 & FP-107 & FP-207 & FP-307 & \begin{tabular}{|c|} 
Accotrol \\
S- 622 \\
\end{tabular} & $\begin{array}{c}\text { PoLEOR } \\
\text { ATC N800 }\end{array}$ \\
\hline & \multicolumn{7}{|c|}{ Polymer system dynamic viscosity $(\mathrm{mPa} \cdot \mathrm{s})$ at shear rate 100 1/s $(117.6 \mathrm{rpm})$} \\
\hline Fresh (distilled) & $48.87 * / 37.01 * *$ & $61.20 * / 38.79 * *$ & $47.69 * / 33.51 * *$ & $44.74 * / 35.39 * *$ & $47.32 * / 46.51 * *$ & $68.82 * / 55.94 * *$ & $28.55 * / 11.21 * *$ \\
\hline Produced $\left(C_{\mathrm{NaCl}}=5 \mathrm{~g} / \mathrm{L}\right)$ & $10.19 * / 42.95 * *$ & $17.33 * / 44.13 * *$ & $15.24 * / 47.69 * *$ & $16.49 * / 21.64 * *$ & $15.80 * / 17.84 * *$ & $69.41 * / 67.65 * *$ & $6.62 * / 10.19 * *$ \\
\hline $\begin{array}{l}\text { Cenomanian } \\
\left(C_{\mathrm{NaCl}}=15 \mathrm{~g} / \mathrm{L}\right)\end{array}$ & $9.68 * / 32.18 * *$ & $13.76^{*} / 31.58^{* *}$ & $11.33 * / 22.08 * *$ & $8.39 * / 17.58 * *$ & $11.09 * / 13.25 * *$ & $9.68 * / 11.72 * *$ & $0.56 * / 6.73 * *$ \\
\hline
\end{tabular}

Note : * - initial dynamic viscosity of the tested polymer composition at $20-25^{\circ} \mathrm{C}$; ** - final dynamic viscosity of the polymer composition after $24 \mathrm{~h}$ at $70^{\circ} \mathrm{C}$. 
Table 3

Conditions and observed parameters of filtration tests on highly permeable core analogues of $\mathrm{VK}_{1}$ horizon field $\mathrm{R}$

\begin{tabular}{|c|c|}
\hline Parameter & Value \\
\hline \multicolumn{2}{|l|}{ Check conditions } \\
\hline Experiment temperature, ${ }^{\circ} \mathrm{C}$ & 70 \\
\hline Confining pressure, $\mathrm{MPa}$ & 31 \\
\hline Pore pressure, $\mathrm{MPa}$ & 10 \\
\hline Fluid injection rate, $\mathrm{cm}^{3} / \mathrm{h}$ & 2.4 \\
\hline Formation oil analogue viscosity, $\mathrm{mPa} \cdot \mathrm{s}$ & 4.07 \\
\hline Formation water analogue viscosity, $\mathrm{mPa} \cdot \mathrm{s}$ & 0.54 \\
\hline Formation water analogue salinity, $\mathrm{g} / \mathrm{L}$ & 12 \\
\hline \multicolumn{2}{|l|}{ Observed parameters } \\
\hline $\begin{array}{l}\text { Grad P during saturation of laboratory formation with } \\
\text { oil, } \mathrm{MPa} / \mathrm{m}\end{array}$ & 0.041 \\
\hline Phase permeability to oil at $K_{\text {init. sat., }} \mu \mathrm{m}^{2} \cdot 10^{-3}$ & 96.56 \\
\hline $\begin{array}{l}\text { Grad P during displacement of oil with water until } \\
\text { filtration of technology compositions of physical and } \\
\text { chemical EOR methods, } \mathrm{MPa} / \mathrm{m}\end{array}$ & 0.130 \\
\hline $\begin{array}{l}\text { Phase permeability to water before treatment at } K_{\text {resid. }} \text {. } \\
\text { sat } \mu \mathrm{m}^{2} \cdot 10^{-3}\end{array}$ & 4.07 \\
\hline $\begin{array}{l}\text { Grad P during displacement of oil with water after } \\
\text { filtration of technology compositions of physical and } \\
\text { chemical EOR methods, } \mathrm{MPa} / \mathrm{m}\end{array}$ & 10.330 \\
\hline $\begin{array}{l}\text { Phase permeability to water after treatment at } K_{\text {resid. sat, }} \\
\mu \mathrm{m}^{2} \cdot 10^{-3}\end{array}$ & 0.05 \\
\hline
\end{tabular}

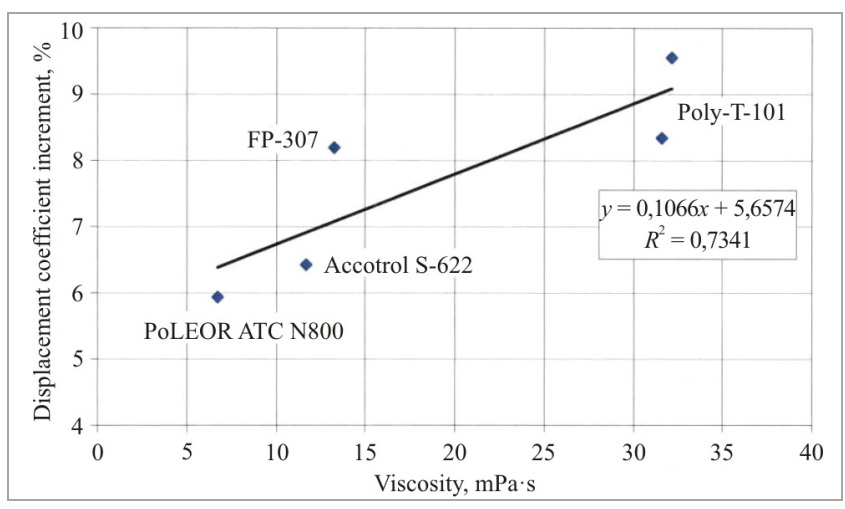

Fig. 2. Dependence of incrementally displaced oil dynamics on final viscosity of polymer compounds based on PAA brands under test injected through laboratory formation VK of field $\mathrm{R}$, mixed on analogue of produced water

waters is limited by the experiment temperature (maximum 50-60 ${ }^{\circ} \mathrm{C}$ ). This phenomenon is demonstrated by further drop in viscosity properties of the tested compounds caused by thermal destruction of interchain bonds of cross-linked gels, in which final stabilization of rheological properties only occurs after $16-20 \mathrm{~h}$.
The performed rheological tests have established that out of all control assays of PAA samples under test, negative influence of the aforementioned factors (sensitivity to brines, thermal stability) is less evident in polymer compositions based on FP-107 and Poly-T-101 reagents, whose final solution viscosities (after $24 \mathrm{~h}$ at $70{ }^{\circ} \mathrm{C}$ ) exceed initial values by more than 2-3 times and are comparable to viscosity of gels prepared using fresh water (table 2).

In case of testing of cross-linked systems based on such PAA brands as FP-207, FP-307, Accotrol S-622, and PoLEOR ATC N800, no multiple increase of final viscosity of polymer systems occurred. The findings can be explained by high sensitivity to low salinity brines in combination with lower thermal destruction threshold (see table 2).

Second stage. Performance of filtration tests to determine permeability coefficient and oil displacement coefficient in use of cross-linked gel structures in highly permeable core analogues of $\mathrm{VK}_{1}$ horizon of field R (table 3).

The identified variances in behavior of viscosity and temperature curves for chromium acetate crosslinked PAA brands fully match the results of their filtration tests on laboratory formation $\mathrm{VK}_{1}$ of field $\mathrm{R}$, where salinity of pore (residual) water and displacement agent amounted to $C_{\mathrm{NaCl}}=12 \mathrm{~g} / \mathrm{L}$. The obtained increments of coefficients of oil displacement with water are located in the interval from 5.94 to $9.55 \%$ and directly depend on final values of polymer systems' dynamic viscosity.

The experiments also established a relative reduction in residual oil saturation of composite columns made up of core samples after treatment with polymer compositions based on the tested polyacrylamide brands, which amounted to: Poly-T$101-5.29$ and $6.13 \%$; Accotrol S-622 - $4.23 \%$, FP$307-5.70 \%$, and PoLEOR ATC N800 - $3.91 \%$ (table 4).

\section{Conclusions}

1. Provided that the stipulated concentrations of gelling agent $\left(\mathrm{C}_{\mathrm{PAA}}=0.4 \mathrm{wt}\right.$. \%) and cross-linking agent $\left(\mathrm{C}_{\mathrm{CA}}=0.04 \mathrm{wt} . \%\right)$ are observed, polymer structures demonstrate high values of initial dynamic viscosity ( 40 to $80 \mathrm{mPa} \cdot \mathrm{s}$ ), which is caused by the final stage of cross-linking microgel complexes due to nearly complete dissolution of PAA in distilled water over a relatively short period of time (30-40 minutes). Among the tested PAA brands, an exception is PoLEOR ATC N800, which does not manifest high thermal stability in fresh water and loses its viscosity properties by more than 2.5 times when the tested sample heating temperature increases up to $50-60{ }^{\circ} \mathrm{C}$. 
Results of determination of residual oil saturation in $\mathrm{VK}_{1}$ laboratory formations of field $\mathrm{R}$ for oil displacement with water before and after filtration of plugs of VEC technology compositions $\left(C_{\mathrm{CA}}=0.04\right.$ wt. $\%, C_{\mathrm{PAA}}=0.4$ wt. $\left.\%\right)$ based on various PAA brands

\begin{tabular}{|c|c|c|c|c|c|c|c|c|c|c|c|c|}
\hline \multirow{2}{*}{ 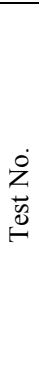 } & \multirow{2}{*}{ PAA brand } & \multirow{2}{*}{$\begin{array}{l}\dot{\dot{z}} \\
\frac{0}{0} \\
\text { 言 } \\
\text { ஸे }\end{array}$} & \multirow{2}{*}{ 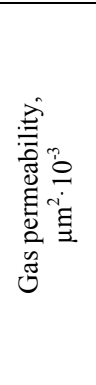 } & \multirow{2}{*}{$\begin{array}{c}0^{0} \\
\stackrel{\overrightarrow{0}}{0} \\
0 \\
0 \\
0\end{array}$} & \multirow{2}{*}{ 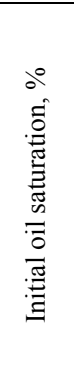 } & \multicolumn{2}{|c|}{$\begin{array}{l}\text { Before injection of } \\
\text { chemical reagent } \\
\text { solutions }\end{array}$} & \multicolumn{2}{|c|}{$\begin{array}{l}\text { After injection of } \\
\text { chemical reagent } \\
\text { solutions }\end{array}$} & \multirow{2}{*}{ 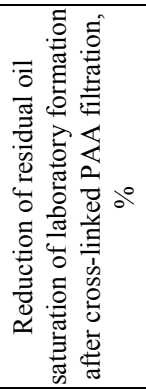 } & \multirow{2}{*}{ 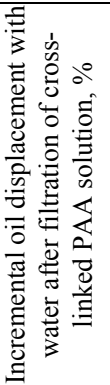 } & \multirow{2}{*}{ 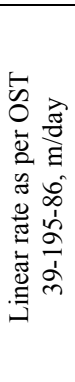 } \\
\hline & & & & & & 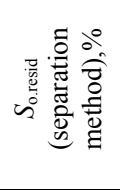 & 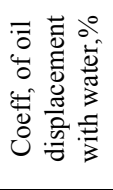 & 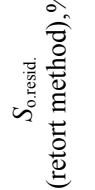 & 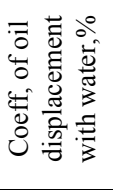 & & & \\
\hline \multirow{4}{*}{1} & \multirow{4}{*}{ POLY-T-101" } & $2860-06$ & 236.40 & 27.32 & 64.01 & \multirow{3}{*}{26.00} & \multirow{3}{*}{59.43} & 20.07 & 68.64 & \multirow{3}{*}{6.13} & \multirow{3}{*}{9.55} & 0.82 \\
\hline & & $8016-06$ & 233.45 & 26.43 & 65.49 & & & 19.70 & 69.92 & & & 0.81 \\
\hline & & 2913-06 & 230.40 & 27.39 & 62.75 & & & 19.84 & 68.38 & & & 0.84 \\
\hline & & Wtd.av.val. & 233.43 & 27.05 & 64.09 & 26.00 & 59.43 & 19.87 & 68.98 & 6.13 & 9.55 & 0.82 \\
\hline \multirow{4}{*}{2} & \multirow{4}{*}{ POLY-T-101 } & $2912-06$ & 225.55 & 27.16 & 61.88 & \multirow{3}{*}{27.50} & \multirow{3}{*}{56.63} & 21.01 & 66.05 & \multirow{3}{*}{5.29} & \multirow{3}{*}{8.35} & 0.90 \\
\hline & & $8003-06$ & 218.11 & 29.31 & 63.18 & & & 22.96 & 63.66 & & & 0.81 \\
\hline & & 7861-07 & 205.15 & 26.85 & 65.01 & & & 22.61 & 65.22 & & & 0.84 \\
\hline & & Wtd.av.val. & 215.93 & 27.75 & 63.41 & 27.50 & 56.63 & 22.21 & 64.98 & 5.29 & 8.35 & 0.85 \\
\hline \multirow{4}{*}{3} & \multirow{4}{*}{ FP-307 } & $2828-06$ & 908.26 & 30.72 & 69.10 & \multirow{3}{*}{28.19} & \multirow{3}{*}{59.42} & 24.01 & 65.26 & \multirow{3}{*}{5.70} & \multirow{3}{*}{8.19} & 0.68 \\
\hline & & $2833-06$ & 896.57 & 28.52 & 70.61 & & & 21.24 & 69.92 & & & 0.71 \\
\hline & & 2839-06 & 879.51 & 28.71 & 68.69 & & & 22.22 & 67.65 & & & 0.74 \\
\hline & & Wtd.av.val. & 894.90 & 29.32 & 69.47 & 28.19 & 59.42 & 22.49 & 67.60 & 5.70 & 8.19 & 0.71 \\
\hline \multirow{4}{*}{4} & \multirow{4}{*}{$\begin{array}{l}\text { Accotrol S- } \\
\quad 622\end{array}$} & $2843-06$ & 884.84 & 27.94 & 65.70 & \multirow{3}{*}{26.86} & & 18.71 & 71.53 & & & 0.79 \\
\hline & & $2821-06$ & 872.70 & 28.20 & 67.58 & & 59.65 & 29.61 & 56.19 & 4.23 & 6.43 & 0.75 \\
\hline & & $2820-06$ & 862.61 & 28.61 & 66.47 & & & 19.80 & 70.22 & & & 0.76 \\
\hline & & Wtd.av.val. & 873.43 & 28.25 & 66.57 & 26.86 & 59.65 & 22.63 & 66.08 & 4.23 & 6.43 & 0.77 \\
\hline & & 2861-06 & 249.95 & 27.17 & 66.13 & & & 25.60 & 61.28 & & & 0.88 \\
\hline & PoLEOR & $2910-06$ & 243.71 & 26.89 & 67.68 & 30.22 & 54.13 & 27.85 & 58.85 & 3.91 & 5.94 & 0.85 \\
\hline 5 & ATC N800 & $2911-06$ & 241.18 & 26.79 & 63.82 & & & 25.50 & 60.04 & & & 0.95 \\
\hline & & Wtd.av.val. & 244.96 & 26.95 & 65.87 & 30.22 & 54.13 & 26.31 & 60.06 & 3.91 & 5.94 & 0.89 \\
\hline
\end{tabular}

2. The performed laboratory tests of rheological properties have established that out of all control assays of PAA samples under test, negative influence of the aforementioned factors (sensitivity to brines, thermal stability) is less evident in polymer compositions based on FP-107 and Poly-T-101 reagents, whose final solution viscosities (after $24 \mathrm{~h}$ at $70{ }^{\circ} \mathrm{C}$ ) exceed initial values by more than $2-3$ times and are comparable to viscosity of gels prepared on fresh water.

3. According to the laboratory analysis findings, we believe that trial injections of cross-linked compositions based on such PAA brands as FP-107 and Poly-T-101 which are capable of causing multiple increase in final viscosity of polymer compositions (by 2-3 times and more) in conditions of temperature increase in low salinity water (produced, Cenomanian), will result in higher process effectiveness than the one obtained with FP-307 acrylamide polymer brand that is presently used at the company fields, previously tested Accotrol S-622 and brands proposed for use - FP-207, PoLEOR ATC N800.

\section{References}

1. Zakirov S.N., Brusilovskii A.I., Zakirov E.S. Sovershenstvovanie tekhnologii razrabotki mestorozhdenii nefti i gaza [Improving oil and gas field development technologies]. Moscow: Graal', 2000, 643 p.

2. Zakirov S.N., Barenbaum A.A., Zakirov E.S., Indrupskiy I.M., Serebryakov V.A., Klimov D.S. Revisiting the development of oil deposits with low permeability reservoirs. Indian Jour nal of Science and Technology, 2016, no. 42, pp. 104219. DOI: 10.17485/ijst/2016/v9i42/104219, November 2016

3. Iagafarov A.K., Kleshchenko I.I., Korotenko V.A. et al. Geologo-promyslovye i technologicheskie aspekty razrabotki neftianykh mestorozhdenii Zapadnoi Sibiri [Geological, production and technological aspects of the development of oil fields in Western Siberia]. Tiumen': Tiumenskii industrial'nyi universitet, 2017, $268 \mathrm{p}$.

4. Iagafarov A.K., Sokhoshko S.K., Kleshchenko I.I. et al. Proektirovanie i modelirovanie razrabotki neftianykh mestorozhdenii Zapadnoi Sibiri 
[Design and modeling of oil development in Western Siberia]. Tiumen': Tiumenskii industrial'nyi universitet, 2017, $215 \mathrm{p}$.

5. Sevast'ianov A.A., Korovin K.V., Zotova O.P. Razrabotka mestorozhdenii $\mathrm{S}$ trudnoizvlekaemymi zapasami nefti [Development of fields with hard-torecover oil reserves]. Tiumen': Tiumenskii industrial'nyi universitet, 2017, $92 \mathrm{p}$.

6. Sevast'ianov A.A., Korovin K.V., Zotova O.P., Zubarev D.I. Osobennosti stroeniia i otsenka potentsiala achimovskikh otlozhenii na territorii KhMAO-Iugry [Structural features and assessment of the potential of the Achimov deposits in the Khanty-Mansi Autonomous Okrug-Ugra]. Uspekhi sovremennogo estestvoznaniia, 2016, no. 8, pp. 195-199.

7. Grachev S.I., Sevast'ianov A.A., Korovin K.V., Zotova O.P., Zubarev D.I. Perspektivy dobychi nefti iz otlozhenii bazhenovskoi svity [Prospects for oil production from sediments of the Bazhenov formation]. Akademicheskii zhurnal Zapadnoi Sibiri, 2018, vol. 14, no. 6 (77), pp. 84-86.

8. Alikhan A.A., Farouq S.M. Current states of nonthermal heavy oil recovery. Препринт SPE 11846 , 1986, pp. 291-298.

9. Jayasekera A.J., Goodyear S.G. The development of heavy oilfields in the United Kindom Continental shelf: past, present and future. SPE Res. Eval. \& Eng, 2000, vol. 5, no. 3, pp. 371-379.

10. Stratiev D., Shishkova I., Pavlova A., Tankov I. Challenges in characterization of residual oils. A review. Journal of Petroleum Science and Engineering, 2019, vol. 178, pp. 227-250.

11. Surguchev M.L. Vtorichnye i tretichnye metody uvelicheniia nefteotdachi plastov [Secondary and tertiary reservoir recovery techniques]. Moscow: Nedra, 1985, 308 p.

12. Muslimov R.Kh. Planirovanie dopolnitel'noi dobychi i otsenka effektivnosti metodov uvelicheniia nefteotdachi plastov [Planning for additional production and evaluating the effectiveness of enhanced oil recovery methods]. Kazan', 1999, 280 p.

13. Gusev S.V. Opyt i perspektivy primeneniia metodov uvelicheniia nefteotdachi na mestorozhdeniiakh Zapadnoi Sibiri [Experience and prospects of application of enhanced oil recovery methods in fields in Western Siberia]. Moscow: VNIIOENG, 1992, $103 \mathrm{p}$.

14. He J.G., Song K.P., Yang J. Study on experiment of advance wa ter injection an example from low permeability oil reservoir of Fuyu oil reservoir in an oil field. Science Technology and Engineering, 2014, vol. 14, no. 11, pp. 181-183.

15. Gusev S.V. Rol' potokootkloniaiushchikh tekhnologii na pozdnikh stadiiakh razvitiia razrabotki mestorozhdenii OAO "Surgutneftegaz" [The role of flow diverting technologies in the late stages of development of OJSC "Surgutneftegas" field development]. Materialy mezhdunarodnoi nauchnoprakticheskoi konferentsii. Казань, 2007, pp. 38-43.

16. Sonich V.P., Misharin V.A., Gusev S.V. Metodicheskie rekomendatsii po primeneniiu fizikokhimicheskikh metodov vozdeistviia na plasty cherez nagnetatel'nye skvazhiny $\mathrm{s}$ tsel'iu regulirovaniia razrabotki neftegazovykh mestorozhdenii OAO "Surgutneftegaz" [Guidelines for the use of physicochemical methods of stimulating reservoirs through injection wells to regulate the development of oil and gas fields of OJSC "Surgutneftegas"]. Tiumen': SurgutNIPIneft', 2008, 79 p.

17. Kondakov A.P., Bairamov V.R., Gusev S.V., Surnova T.M. Primenenie potokootkloniaiushchikh tekhnologii dlia ogranicheniia vodopritoka v dobyvaiushchikh skvazhinakh [The use of flow deviation technologies to limit water production in producing wells]. Neftianoe khoziaistvo, 2012, no. 8, pp. 34-35.

18. Gusev S.V., Surnova T.M., Fedoseev S.A., Bairamov V.R. Sostoianie primeneniia potokootkloniaiushchikh metodov uvelicheniia nefteotdachi na plaste BS10 Konitlorskogo mestorozhdeniia [Application of flow deflection methods of oil recovery increase at BS100 layer of Konitlorskoye field]. Neftianoe khoziaistvo, 2010, no. 12 , pp. 106-108.

19. Kondakov A.P., Gusev S.V., Surnova T.M. Opyt primeneniia fiziko-khimicheskikh metodov uvelicheniia nefteotdachi plasta IuS 2 mestorozhdenii OAO "Surgutneftegaz" [Experience of the use of physical and chemical methods of enhanced oil recovery of YuS 2 layers of Surgutneftegs OJSC fields]. Neftianoe khoziaistvo, 2013, no. 9, pp. 47-49.

20. Kondakov A.P., Gusev S.V., Surnova T.M., Bairamov V.R. Rezul'taty primeneniia tekhnologii ogranicheniia vodopritoka $\mathrm{v}$ dobyvaiushchie skvazhiny $\mathrm{v}$ usloviiakh nizkopronitsaemykh kollektorov [The results of the application of technology to reduce water production of producing wells at low permeability reservoirs]. Neftianoe khoziaistvo, 2014, no. 10 , pp. 100-101.

21. Kondakov A.P., Gusev S.V., Narozhnyi O.G. Rezul'taty bol'sheob"emnykh obrabotok prizaboinoi zony nagnetatel'nykh skvazhin mestorozhdenii OAO "Surgutneftegaz" [The results of large-volume matrix acidizing treatments in injection wells in JS2 formations at the Surgutneftegas OJSC fields]. Neftianoe khoziaistvo, 2016, no. 9, pp. 74-77.

22. Aldakimov F.Iu., Gusev S.V., Ogorel'tsev V.Iu., Grebenkina E.O. Rezul'taty i perspektivy primeneniia osadkogeleobrazuiushchikh sostavov dlia uvelicheniia nefteotdachi plasta AS 4-8 Fedorovskogo mestorozhdeniia [Results and 
prospects of application of deposit and gel forming compositions for enhancing oil recovery of AS 4-8 layer of Fedorovskoye field]. Neftianoe khoziaistvo, 2014, no. 5, pp. 87-89.

23. Ogorel'tsev V.Iu., Leont'ev S.A. Rezul'taty primeneniia osadkogeleobrazuiushchikh sostavov (OGS) dlia uvelicheniia nefteotdachi plasta Fedorovskogo mestorozhdeniia [The results of the use of sediment-forming compounds (OGS) to increase oil recovery of the Fedorovskoye field]. Geologiia $i$ neftegazonosnost' Zapadno-Sibirskogo megabasseina (opyt, innovatsii). Materialy desiatoi Mezhdunarodnoi nauchno-tekhnicheskoi konferentsii (posviashchennoi 60-letiiu Tiumenskogo industrial'nogo universiteta). Tiumen': Tiumenskii industrial'nyi universitet, 2016, pp. 104-107.

24. Diagilev V.F., Polishchuk S.E., Leont'ev S.A., Spasibov V.M. Analiz rezul'tatov trassernykh issledovanii na primere plasta $\mathrm{AS}_{1-3}$ SeveroOrekhovskogo mestorozhdeniia [Analysis of the results of tracer studies on the example of the AS1-3 formation of the North Orekhovskoye field]. Izvestiia vysshikh uchebnykh zavedenii. Neft' $i$ gaz, 2018, no. 4 , pp. $44-51$

25. Diagilev V.F., Kononenko A.A., Leont'ev S.A. Analiz rezul'tatov trassernykh issledovanii na primere plasta IuV11 Chistinnogo mestorozhdeniia [Analysis of the results of tracer studies on the example of the YuV11 layer of the Chistin field] Uspekhi sovremennogo estestvoznaniia, 2018, no. 1, pp. 93-101.

26. Grigorashchenko G.I. Zaitsev Iu.V., Kukin V.V. et al. Primenenie polimerov v dobyche nefti [The use of polymers in oil production]. Moscow: Nedra, 1978, 213 p.

27. Vlasov S.A., Kagan Ia.M., Fomin A.V. Novye perspektivy polimernogo zavodneniia $\mathrm{v}$ Rossii [New Perspectives of Polymer Flooding in Russia]. Neftianoe khoziaistvo, 1998, no. 5, pp. 46-49.

28. Li H., Li Y., Wang K., Luo H., Chen S., Guo J. Effect of chemical additives on dynamic capillary pressure during waterflooding in low permeability reservoirs. Energy and Fuels, 2016, no. 9, pp. 7082-7093.

29. Polishchuk S.E., Diagilev V.F., Leont'ev S.A. Obosnovanie primeneniia polimernogo zavodneniia na novomolodezhnom mestorozhdenii [The rationale for the use of polymer flooding in a new field]. Geologiia $i$ neftegazonosnost' Zapadno-Sibirskogo megabasseina (opyt, innovatsii). Materialy desiatoi Mezhdunarodnoi nauchno-tekhnicheskoi konferentsii (posviashchennoi 60-letiiu Tiumenskogo industrial'nogo universiteta). Tiumen': Tiumenskii industrial'nyi universitet, 2016, pp. 119-123.

30. Mikhail R., Artem K. Experiments of fluid diversion ability of a new waterproofing polymer solution. Shiyou Kantan Yu Kaifa, 2015, vol. 42, no. 4, pp. 507-511.

31. Liu W., Wei Y., Jiang W., Luo L., Liao G., Zuo L. Experimental study on the mechanism of enhancing oil recovery by polymer - surfactant binary flooding. Petroleum Exploration and Development, 2017, vol. 44, no. 4, pp. 636-643.

32. Gumerova G.R., Iarkeeva N.R. Analiz effektivnosti primeneniia viazkouprugogo poverkhnostno-aktivnogo sostava na mestorozhdeniiakh Zapadnoi Sibiri [Analysis of the effectiveness of the application of a viscoelastic surfactant in the fields of Western Siberia]. Izvestiia Tomskogo politekhnicheskogo universiteta. Inzhiniring georesursov, 2019, vol. 330, no. 1, pp. 19-25.

33. Li J., Jia R., Liu W., Sun L., Cong S., Yang Y., Zhang J. Effect of emulsification on surfactant partitioning in surfactant-polymer flooding. Journal of Surfactants and Detergents, 2019, vol. 22, no. 6, pp. 1387-1394.

34. Rezul'taty primeneniia fiziko-khimicheskikh metodov uvelicheniia nefteotdachi na mestorozhdeniiakh PAO "Surgutneftegaz": otchet o NIR [The results of the application of physicochemical methods of increasing oil recovery in the fields of PJSC "Surgutneftegas": report on research]. Tiumen': SurgutNIPIneft', 2011, 98 p.

35. GOST 26450.0-85. Porody gornye. Obshchie trebovaniia $\mathrm{k}$ otboru $\mathrm{i}$ podgotovke prob dlia opredeleniia kollektorskikh svoistv [GOST 26450.0-85. The rocks are mountain. General requirements for the collection and preparation of samples to determine reservoir properties]. Moscow, 1985.

36. GOST 26450.1-85. Porody gornye. Metod opredeleniia koeffitsienta otkrytoi poristosti zhidkostenasyshcheniem [GOST 26450.1-85. The rocks are mountain. Method for determining the coefficient of open porosity by liquid saturation]. Moscow, 1985.

37. GOST 26450.2-85. Porody gornye. Metod opredeleniia koeffitsienta absoliutnoi gazopronitsaemosti pri fil'tratsii [GOST 26450.2-85. The rocks are mountain. Method for determination of absolute gas permeability coefficient during filtration]. Moscow, 1985.

38. OST 39-195-86. Neft'. Metod opredeleniia koeffitsienta vytesneniia nefti vodoi v laboratornykh usloviiakh [OST 39-195-86. Oil. Method for determining the coefficient of oil displacement by water in laboratory conditions]. Moscow, 1986.

39. OST 39-235-89. Neft'. Metod opredeleniia fazovykh pronitsaemostei $\mathrm{v}$ laboratornykh usloviiakh pri sovmestnoi statsionarnoi fil'tratsii [OST 39-235-89. Oil. Method for determination of phase permeabilities 
in laboratory conditions with joint stationary filtration]. Moscow, 1989.

40. Rogachev M.K., Kondrashev A.O.Rheological studies of waterproof polymeric compounds under high pressure and temperature. Life Science Journal, 2014, vol. 11, no. 6s, pp. 294-296.

41. Iuril Ia.E., Leont'ev S.A., Rogalev M.S. Analiz sushchestvuiushchikh metodik po provedeniiu termodinamicheskikh issledovanii plastovykh fliuidov $\mathrm{v}$ PAO "GAZPROM" [The analysis of the existing methods of thermodynamic studies the formation fluids in "Gazprom"]. Ekspozitsiia. Neft'. Gaz, 2016, vol. 50, no. 4 , pp. 48-50.

42. Korotenko V.A., Kushakova N.P., Leont'ev S.A., Zaboeva M.I., Aleksandrov M.A. Zavisimost' koeffitsientov nasyshchennosti ot vremeni i koordinat [Dependence of saturation coefficients on time and coordinates]. Izvestiia vysshikh uchebnykh zavedenii. Нефть и газ, 2016, nо. 6, pp. 74-81.

43. Korotenko V.A., Grachev S.I., Kushakova N.P., Leontiev S.A., Zaboeva M.I., Aleksandrov M.A. On modeling of non-stationary two-phase filtration. IOP Conference Series: Earth and Environmental Science, 2018, $012016 \mathrm{p}$.

44. Grachev S.I., Korotenko V.A., Kushakova N.P., Kriakvin A.B., Zotova O.P. Fil'tratsiia zhidkostei $\mathrm{v}$ anomal'nykh kollektorakh [Liquid filtration in anomalous collectors]. Izvestiia Tomskogo politekhnicheskogo universiteta. Inzhiniring georesursov, 2019, vol. 330, no. 7, pp. 104-113.

45. Grachev S.I., Korotenko V.A., Kushakova N.P. Issledovanie vliianiia transformatsii dvukhfaznoi fil'tratsii na formirovanie zon nevyrabotannykh zapasov nefti [Study on influence of two-phase filtration transformation on formation of zones of undeveloped oil reserves]. Zapiski Gornogo instituta, 2020, vol. 241, pp. 68-82.

\section{Библиографический список}

1. Закиров С.Н., Брусиловский А.И., Закиров Э.С. Совершенствование технологий разработки месторождений нефти и газа. - М.: Грааль, 2000. -643 c.

2. Revisiting the development of oil deposits with low permeability reservoirs / S.N. Zakirov, A.A. Barenbaum, E.S. Zakirov, I.M. Indrupskiy, V.A. Serebryakov, D.S. Klimov // Indian Jour nal of Science and Technology. - 2016. - № 42. - P. 104219. DOI: 10.17485/ijst/2016/v9i42/104219, November 2016.

3. Геолого-промысловые и технологические аспекты разработки нефтяных месторождений Западной Сибири / А.К. Ягафаров, И.И. Клещенко, В.А. Коротенко [и др.]. - Тюмень: Изд-во ТИУ, 2017. $-268 \mathrm{c}$.
4. Проектирование и моделирование разработки нефтяных месторождений Западной Сибири / А.К. Ягафаров, С.К. Сохошко, И.И. Клещенко [и др.]. - Тюмень: Изд-во ТИУ, 2017. -215 с.

5. Севастьянов А.А., Коровин К.В., Зотова О.П. Разработка месторождений с трудноизвлекаемыми запасами нефти. - Тюмень: Изд-во ТИУ, 2017. $-92 \mathrm{c}$.

6. Особенности строения и оценка потенциала ачимовских отложений на территории ХМАОЮгры / А.А. Севастьянов, К.В. Коровин, О.П. Зотова, Д.И. Зубарев // Успехи современного естествознания. - 2016. - № 8. - С. 195-199.

7. Перспективы добычи нефти из отложений баженовской свиты / С.И. Грачев, А.А. Севастьянов, К.В. Коровин, О.П. Зотова, Д.И. Зубарев // Академический журнал Западной Сибири. - 2018. T. 14. № 6 (77). - C. 84-86.

8. Alikhan A.A., Farouq S.M. Current states of nonthermal heavy oil recovery // Препринт SPE 11846. 1986. - P. 291-298.

9. Jayasekera A.J., Goodyear S.G. The development of heavy oilfields in the United Kindom Continental shelf: past, present and future // SPE Res. Eval. \& Eng. - 2000. - Vol. 5, № 3. - P. 371-379.

10. Challenges in characterization of residual oils. A review / D. Stratiev, I. Shishkova, A. Pavlova, I. Tankov // Journal of Petroleum Science and Engineering. - 2019. - Vol. 178. - P. 227-250.

11. Сургучев М.Л. Вторичные и третичные методы увеличения нефтеотдачи пластов. М.: Недра, 1985. - 308 с.

12. Муслимов Р.Х. Планирование дополнительной добычи и оценка эффективности методов увеличения нефтеотдачи пластов. - Казань, 1999. $-280 \mathrm{c}$.

13. Гусев С.В. Опыт и перспективы применения методов увеличения нефтеотдачи на месторождениях Западной Сибири. - М.: Изд-во ВНИИОЭНГ, 1992. - 103 с.

14. He J.G., Song K.P., Yang J. Study on experiment of advance wa ter injection an example from low permeability oil reservoir of Fuyu oil reservoir in an oil field // Science Technology and Engi neering. - 2014. - Vol. 14, № 11. - P. 181-183.

15. Гусев С.В. Роль потокоотклоняющих технологий на поздних стадиях развития разработки месторождений. ОАО «Сургутнефтегаз» // Материалы международной научно-практической конференции, Казань, 2007. - С. 38-43.

16. Сонич В.П., Мишарин В.А., Гусев С.В. Методические рекомендации по применению физико-химических методов воздействия на пласты через нагнетательные скважины с целью регулирования разработки нефтегазовых месторождений 
ОАО «Сургутнефтегаз». - Тюмень: Изд-во СургутНИПИнефть, 2008. - 79 с.

17. Применение потокоотклоняющих технологий для ограничения водопритока в добывающих скважинах / А.П. Кондаков, В.Р. Байрамов, С.В. Гусев, Т.М Сурнова // Нефтяное хозяйство. 2012. - № 8. - С. 34-35.

18. Состояние применения потокоотклоняющих методов увеличения нефтеотдачи на пласте БС10 Конитлорского месторождения / С.В. Гусев, T.М. Сурнова, С.А. Федосеев, В.Р. Байрамов // Нефтяное хозяйство. - 2010. - № 12 . C. $106-108$.

19. Кондаков А.П., Гусев С.В., Сурнова Т.М. Опыт применения физико-химических методов увеличения нефтеотдачи пласта ЮС 2 месторождений ОАО «Сургутнефтегаз» // Нефтяное хозяйство. - 2013. - № 9. - С. 47-49.

20. Результаты применения технологий ограничения водопритока в добывающие скважины в условиях низкопроницаемых коллекторов / А.П. Кондаков, С.В. Гусев, Т.М. Сурнова, В.Р. Байрамов // Нефтяное хозяйство. - 2014. - № 10 . C. $100-101$.

21. Результаты большеобъемных обработок призабойной зоны нагнетательных скважин месторождений ОАО «Сургутнефтегаз» / А.П. Кондаков, С.В. Гусев, О.Г. Нарожный // Нефтяное хозяйство. 2016. - № 9. - С. 74-77.

22. Результаты и перспективы применения осадкогелеобразующих составов для увеличения нефтеотдачи пласта АC 4-8 Федоровского месторождения / Ф.Ю. Алдакимов, С.В. Гусев, В.Ю. Огорельцев, Е.О. Гребенкина // Нефтяное хозяйство. - 2014. - № 5. - С. 87-89.

23. Огорельцев В.Ю., Леонтьев С.А. Результаты применения осадкогелеобразующих составов (ОГС) для увеличения нефтеотдачи пласта Федоровского месторождения // Геология и нефтегазоносность Западно-Сибирского мегабассейна (опыт, инновации) материалы десятой международной научнотехнической конференции (посвященной 60-летию Тюменского индустриального университета). Тюмень: Изд-во ТИУ, 2016. - С. 104-107.

24. Анализ результатов трассерных исследований на примере пласта $\mathrm{AC}_{1-3}$ СевероОреховского месторождения / В.Ф. Дягилев, С.Е. Полищук, С.А Леонтьев, В.М. Спасибов // Известия высших учебных заведений. Нефть и газ. 2018. - № 4. - C. 44-51

25. Дягилев В.Ф., Кононенко А.А., Леонтьев С.А. Анализ результатов трассерных исследований на примере пласта ЮВ11 Чистинного месторождения // Успехи современного естествознания. 2018. - № 1. - С. 93-101.
26. Применение полимеров в добыче нефти / Г.И. Григоращенко Ю.В. Зайцев, В.В. Кукин [и др.]. М.: Недра, 1978. - 213 с.

27. Власов С.А., Я.М. Каган, А.В. Фомин Новые перспективы полимерного заводнения в России // Нефтяное хозяйство - 1998. - № 5. - C. 46-49.

28. Effect of chemical additives on dynamic capillary pressure during waterflooding in low permeability reservoirs / H. Li, Y. Li, K. Wang, H. Luo, S. Chen, J. Guo // Energy and Fuels. - 2016. - № 9. P. 7082-7093.

29. Полищук С.Е., Дягилев В.Ф., Леонтьев С.А. Обоснование применения полимерного заводнения на новомолодежном месторождении // Геология и нефтегазоносность Западно-Сибирского мегабассейна (опыт, инновации) материалы десятой международной научно-технической конференции (посвященной 60-летию Тюменского индустриального университета). - Тюмень: Изд-во ТИУ. 2016. - C. 119-123.

30. Mikhail R., Artem K. Experiments of fluid diversion ability of a new waterproofing polymer solution // Shiyou Kantan Yu Kaifa. - 2015. Vol. 42, № 4. - P. 507-511.

31. Experimental study on the mechanism of enhancing oil recovery by polymer - surfactant binary flooding / W. Liu, Y. Wei, W. Jiang, L. Luo, G. Liao, L. Zuo // Petroleum Exploration and Development. 2017. - Vol. 44, № 4. - Р. 636-643.

32. Гумерова Г.Р., Яркеева Н.Р. Анализ эффективности применения вязкоупругого поверхностно-активного состава на месторождениях Западной Сибири // Известия Томского политехнического университета. Инжиниринг георесурсов. 2019. - T. 330, № 1. - С. 19-25.

33. Effect of emulsification on surfactant partitioning in surfactant-polymer flooding / J. Li, R. Jia, W. Liu, L. Sun, S. Cong, Y. Yang, J. Zhang // Journal of Surfactants and Detergents, 2019. - Vol. 22, № 6. - P. 1387-1394.

34. Результаты применения физико-химических методов увеличения нефтеотдачи на месторождениях ПАО «Сургутнефтегаз»: отчет о НИР. - Тюмень: Изд-во СургутНИПИнефть, 2011. -98 c.

35. ГОСТ 26450.0-85. Породы горные. Общие требования к отбору и подготовке проб для определения коллекторских свойств. М., 1985.

36. ГОСТ 26450.1-85. Породы горные. Метод определения коэффициента открытой пористости жидкостенасыщением. - М., 1985.

37. ГОСТ 26450.2-85. Породы горные. Метод определения коэффициента абсолютной газопроницаемости при фильтрации. - М., 1985. 
38. ОСТ 39-195-86. Нефть. Метод определения коэффициента вытеснения нефти водой в лабораторных условиях. - М., 1986.

39. ОСТ 39-235-89. Нефть. Метод определения фазовых проницаемостей в лабораторных условиях при совместной стационарной фильтрации. M., 1989.

40. Rogachev M.K., Kondrashev A.O.Rheological studies of waterproof polymeric compounds under high pressure and temperature // Life Science Journal. 2014. - Vol. 11, № 6s. - P. 294-296.

41. Юрил Я.Э., Леонтьев С.А., Рогалев М.С. Анализ существующих методик по проведению термодинамических исследований пластовых флюидов в ПАО «ГАЗПРОМ» // Экспозиция. Нефть. Газ. - 2016. - Т. 50, № 4 . - С. 48-50.

42. Зависимость коэффициентов насыщенности от времени и координат / В.А. Коротенко, Н.П. Кушакова, С.А. Леонтьев, М.И. Забоева,
М.А. Александров // Известия высших учебных заведений. Нефть и газ. - 2016. - № 6. C. $74-81$.

43. On modeling of non-stationary two-phase filtration / V.A. Korotenko, S.I. Grachev, N.P. Kushakova, S.A. Leontiev, M.I. Zaboeva, M.A. Aleksandrov // IOP Conference Series: Earth and Environmental Science, 2018. - P. 012016.

44. Фильтрация жидкостей в аномальных коллекторах / С.И. Грачев, В.А. Коротенко, Н.П. Кушакова, А.Б. Кряквин, О.П. Зотова // Известия Томского политехнического университета. Инжиниринг георесурсов. - 2019. - Т. 330, № 7. C. 104-113.

45. Грачев С.И., Коротенко В.А., Кушакова Н.П. Исследование влияния трансформации двухфазной фильтрации на формирование зон невыработанных запасов нефти // Записки Горного института. - 2020. T. 241. - C. $68-82$.

Please cite this article in English as:

Ogoreltcev V.Iu., Leontev S.A., Korotenko V.A., Grachev S.I., Diagilev V.F., Fominykh O.V. Laboratory studies of the influence of rheological characteristics of cross-linked polymer systems on oil permeability and displacement coefficients. Perm Journal of Petroleum and Mining Engineering, 2020, vol.20, no.2, pp.162-174. DOI: 10.15593/2224-9923/2020.2.6

Просьба ссылаться на эту статью в русскоязычных источниках следующим образом:

Лабораторные исследования влияния реологических характеристик сшитых полимерных систем на коэффициенты проницаемости и вытеснения нефти / В.Ю. Огорельцев, С.А. Леонтьев, В.А. Коротенко, С.И. Грачев, В.Ф. Дягилев, О.В. Фоминых // Вестник Пермского национального исследовательского политехнического университета. Геология. Нефтегазовое и горное дело. - 2020. - Т.20, №2. - C.162-174. DOI: 10.15593/2224-9923/2020.2.6 